\title{
BEST WORST METODU İLE İNŞAAT SEKTÖRÜNDE RİSK DEĞERLENDİRMESİNE YENİ BİR YAKLAŞIM
}

\author{
Necip Fazil KARAKURT², İhsan HEKIMMĞLU², Ali GUNERİ² \\ ${ }^{1}$ Tekirdağ Namık Kemal Üniversitesi, Mühendislik Fakültesi, Endüstri Mühendisliği Bölümü, Çorlu, Tekirdağ \\ ${ }^{2}$ Yıldız Teknik Üniversitesi, Makine Fakültesi, Endüstri Mühendisliği Bölümü, Beşiktaş, İstanbul
}

\begin{tabular}{|c|c|}
\hline Anahtar Kelimeler & Öz \\
\hline $\begin{array}{l}\text { Best Worst Metot, } \\
\text { Inşaat Sanayi, } \\
\text { Risk Önceliklendirme, } \\
\text { Risk Değerlendirme. }\end{array}$ & 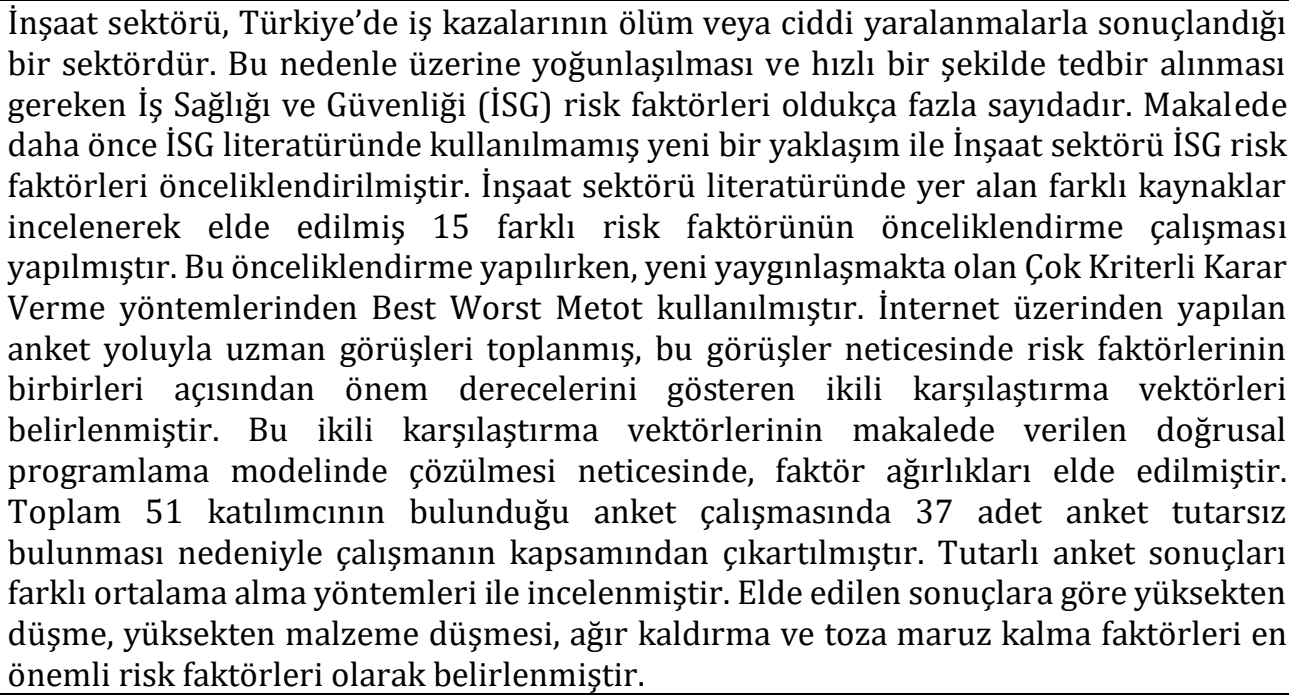 \\
\hline
\end{tabular}

\section{A NOVEL RISK ASSESSMENT APPROACH ON CONSTRUCTION INDUSTRY USING BEST WORST METHOD}

\begin{tabular}{ll}
\hline Keywords & Abstract \\
\hline $\begin{array}{l}\text { Best Worst Method, } \\
\text { Ronstruction Industry, }\end{array}$ & $\begin{array}{l}\text { Construction is an industry where most of the work accidents end up with death or } \\
\text { severe injury. Therefore there are lots of risk factors need to be focused and taken }\end{array}$ \\
Risk Assessment. & measure. In this paper, a novel method is used to prioritize risk factors and find out the \\
& most important ones to deal with. In this paper, 15 risk factors are collected from \\
academic papers concerning construction industry. The risk factors are prioritized by & a brand new multiple criteria decision (MCDM) technique, Best-Worst method. The \\
method, as other MCDM tecniques, is based on getting pairwise importance level of \\
factors from decision maker. Decision makers filled out the questionnaire on the \\
internet due to severe pandemic. Pairwise comparison vector results are used in linear \\
programming model that results in factor weights after being solved. Result of 51 \\
participants has been analyzed in order to sort inconsistent answers out. By excluding \\
inconsistent answers, falling down from height, material drop from height, lifting heavy \\
and being exposed to dust are found to be most important factors when different kind \\
of average methods are taken into consideration for multiple decision makers.
\end{tabular}

Alıntı / Cite

Karakurt, N.F., Hekimoglu, I., Guneri., (2021). Best Worst Metodu ile İnşaat Sektöründe Risk Değerlendirmesine Yeni Bir Yaklaşim, Mühendislik Bilimleri ve Tasarım Dergisi, 9(4), 1141-1154.

\footnotetext{
* ilgili yazar / Corresponding author: nfkarakurt@gmail.com
} 
Yazar Kimliği / Author ID (ORCID Number)

N.F. Karakurt, 0000-0003-2284-6800

İ. Hekimoğlu, 0000-0003-1945-4304

A. Guneri, 0000-0003-2525-7278
Makale Süreci / Article Process

Başvuru Tarihi / Submission Date

Revizyon Tarihi / Revision Date

Kabul Tarihi / Accepted Date

Yayım Tarihi / Published Date
20.07.2020

22.08 .2021

01.09 .2021

20.12 .2021

\section{Giriş (Introduction)}

İş Sağlı̆̆ı ve Güvenliği (İSG) alanında yapılan çalışmalar belirli bir birikim oluşturmuş olup bu birikimin yeni çalışmalarla sürekli kendini yenilemesi ve geliştirmesi gerekmektedir (Uzun, 2012). Bu alanda yapılan çalışmalarda risklerin değerlendirilmesi amacıyla kullanılan pek çok yöntem vardır. Risk değerlendirme yöntemi ve veri toplama araçlarını tasarlarken, tasarımı ve uygulamayı gerçekleştiren çalışanların yüksek bir eğitim düzeyine sahip olması, çalışılan yöntemin güvenilir sonuçlara ulaşabilmesi için önemli bir faktör olmaktadır. Riskleri ve önem derecelerini belirlemek adına yapılan akademik çalışmalar, ne kadar kolay anlaşılır olursa, risklerin ve önem derecelerinin belirlenmesi de o kadar kolay olacaktır. Bu nedenle sürekli yeni risk değerlendirme yöntemlerinin ortaya konması ve sahada denenerek geçerliliğinin test edilmesi gerekmektedir.

Risk yönetimi, birçok teknik değerlendirmeyi ve teknik yardım gerektiren araçları sürece dahil ederek, daha güçlü şekilde ifade edilebilen, şeffaf ve hesap verebilir bir anlayışla, alınan kararları yönetebilmeyi sağlar. İSG risk yönetimi, bir kuruma faaliyetlerle ilgili tehlikeleri daha iyi anlama, öngörme, iç ve dış koşullardaki değişikliklere hızlı ve etkili şekilde cevap verebilme yeteneği kazandırır (Özkılıç, 2005). İSG risklerinin yönetilmesi, bir kuruma doğrudan yarar sağlanması için rehberlik eder. İSG risklerinin yönetilmesi;

- İş kazaları ve meslek hastalıklarının azalmasını sağlar,

- Kaynakların etkin kullanımını sağlar, bu da tasarruf anlamına gelir,

- Yöneticilerin daha anlamlı bilgilere ulaşarak, daha iyi kararlar almalarına yardım eder,

- İSG kanunları ile entegrasyonu kolaylaştırır (Özkılıç, 2005).

Risk değerlendirmesi tehlikenin yarattığı riski ve bu tehlikeye karşı alınan önlemlerin bu riskleri kabul edilebilir seviyelere çekip çekmediğinin incelenmesi olarak tanımlanabilir. (Laitinen vd., 2012). Risk değerlendirmesine yönelik ilk bilimsel alışmalar 1950’li yıllara dayanmaktadır. Bu amaçla kullanılan analiz yöntemleri, kullanım yerlerine göre yıllar içinde gelişim göstermiştir. Bu kapsamdaki çalışmalar, kazaların sınırlandırılmasından, alternatif risk değerlendirme metotlarının geliştirilmesine kadar, geniş bir aralıkta değişmektedir. Makin ve Winder (2008) riskleri yönetim kolaylı̆̆ı için ana gruplara ayırarak incelemiştir. Bu gruplar yönetim, fiziksel çevre ve bunun gibi riskle ilgili konulardan oluşmaktadır.

Çalışmada risk analizinde en sık kullanılan yöntemler ana başlıklarıyla açıklanmış, daha düşük sıklıkta kullanılan yöntemler ise isimleri hatırlatılarak listelenmiştir. Bu çalışmada yeni geliştirilen bir Çok Kriterli Karar Verme (ÇKKV) yöntemi olan Best Worst Metot (BWM) ele alınmıştır. Bu metot daha önce farklı amaçlar için kullanılmış olsa da yöntemin risk değerlendirme amacıyla kullanıldı̆̆ı yeterli sayıda çalışmaya rastlanmamıștır. BWM'nin amacı, uygulama adımları ve avantajları açıklanmış, metodun kullanıldığı literatür kapsamlı şekilde araştırılarak, metodun kullanıldığı sektörler ve kullanım amaçları detaylı olarak ortaya konmuştur. BWM'nin risk değerlendirme amacıyla kullanıldığı bir uygulama çalışması yapmaktaki amaç, bu metodun İSG alanında risklerin önem derecelerinin belirlenmesinde kullanılabilirliğini göstermektir. Araştırmada elde edilen sonuçlar bilimsel olarak ortaya konmuş ve bu yeni yaklaşımın akademik çevrelerde daha fazla benimsenmesini sağlamak amaçlanmıştır. BWM ile bir uygulama çalışması yapmak ve sonuçlarını ortaya koymak amacıyla inşaat sektörü tercih edilmiştir. Bu amaçla bir anket düzenlemiş ve inşaat sektörü profesyonelleri, iş sağlığı ve güvenliği uzmanları, iş sağlığı ve güvenliği doktora programı öğrencilerinden oluşan bir örneklem grubuna sunulmuştur. Sonuçta en yüksek risk faktörlerinin hangileri olduğu, BWM ile analiz edilerek elde edilen bulgular çalışmanın ilerleyen bölümlerinde ortaya konmuştur.

Gerçekleşme ihtimali olan ancak gerçekleşeceği zaman ve gerçekleştiğinde ortaya çlkacak sonucun şiddeti net olarak bilinemeyen olaylara risk denilir. Riskler değerlendirilirken öncelikli olarak tehlikeler tanımlanmalıdır. Bu tehlikelere ilişkin risk değerlendirmesi yapılarak bunların kontrol altına alınmasına yönelik tedbirler belirlenmelidir. Sonrasında bu tedbirlerin uygulamaya alınması ile birlikte süreç izlenmelidir (Selçuk ve Selim, 2018). Risk analizlerinde risklerin önlenmesi konusunda iki ana yaklaşım mevcuttur. Bunlar reaktif ve proaktif yaklaşımlardır. Reaktif yaklaşımda müdahale olay sonrasında gelir ve olayın tekrar yaşanmamasına yönelik tedbirler alınması sağlanır. Proaktif yaklaşımda ise bunun tam tersi olarak olay yaşanmadan, herhangi bir iş kazası ve can kaybı olmadan önlemler alınmaya başlanır (Özkılıç, 2007). Risk analizi için nitel ve nicel yöntemler bulunmaktadır. Nitel yöntemlerde riskler sayısal olarak puanlandırılmaz, bunun yerine sözel ifadelerle riskin boyutu ve etkisi nitelendirilmeye çalışllır (Topal, 2017). Risk analiz yöntemlerinin en bilinenleri; Neden Sonuç 
Analizi, HTA-Hata Ağacı Analizi, What if-Olursa Ne Olur Analizi, Neden Sonuç Analizi, HAZOP-Tehlike ve İşletilebilme Yöntemi, PHA-Ön Tehlike Analizi ve HTA-Hiyerarşik Görev Analizidir. Nicel yöntemlerde sözel ifadeler yerine riskler nümerik değerlerle ifade edilir. Bu değerler çoğunlukla olasılık yardımıyla elde edilir (Topal, 2017). En bilinen yöntemler; FMEA- Olası Hata Türleri ve Etkileri Analizi, L Tipi ve X Matris ve Fine-Kinney Risk Analizidir. Bahsi geçen yöntemlerin dışında, Çok Kriterli Karar Verme teknikleri de risk analizinde kullanılmaktadır.

Çalışma şu şekilde organize edilmiştir; Bölüm 2'de BWM'nin kullanım alanları hakkında kapsamlı literatür taraması yer almaktadır. Kullanılan yöntemin özellikleri ve uygulama adımları Bölüm 3'te verilmiş olup uygulanan anketin ve BWM yaklaşımının detaylı sonuçları Bölüm 4 ile verilmiştir. Bölüm 5 ile çalışmada elde edilen sonuçlar, çalışmanın çıktıları ve kısıtları ele alınmıştır.

\section{Kaynak Araştırması (Literature Survey)}

BWM, 2015 yılında Jafar Rezeai tarafından en iyi alternatifi seçmek için, bir dizi kriter açısından bir dizi alternatif değerlendirilmesi problemine çözüm olarak önerilmiştir (Rezeai, 2015). Daha sonraki yıllarda, Kara ve Fırat (2018) yaptıkları çalışmada tedarikçi risk değerlendirmesi için BWM ile birlikte kümeleme analizi uygulamışlardır. Farklı risk faktörleri uzman görüşleri ile ağırlıklandırılmış ve önem derecelerine göre sıralanmıştır. Chang vd. (2019) yaptıkları çalışmada BWM ve TOPSIS yöntemleriyle FMEA çalışması yapmışlardır. Elde edilen model geleneksel yöntemin birçok zayıf noktasına çözüm sunmuştur. Norouzi ve Namin (2019) yaptıkları çalışmada inşaat sektöründeki proje risklerini önceliklendirmişlerdir. Çalışmada iki aşamalı bir yaklaşım (TOPSIS ve BWM) önermişlerdir. Çakır ve Can (2019) yaptıkları çalışmada konaklama işletmelerinin dış kaynak seçiminde önemli ölçütlerin BWM'ye dayalı ARAS yöntemiyle belirlenmesini amaçlamışlardır. Çalışma neticesinde konaklama işletmesinin çamaşır yıkama fabrikası seçiminde göz önünde bulundurduğu fiyat, iş birliği, kalite, teslimat ve hijyen olmak üzere 5 ana kriter ve söz konusu ana kriterler altında 16 alt kriter belirlenmiştir. Çakır ve İncioğlu (2019) çalışmasında gayrimenkul satın almada, doğrudan yabancı yatırımcı için etkin rol oynayan faktörleri (beklentileri) belirlemiștir. Bu faktörlerin önem düzeylerini BWM ile analiz etmiștir. Yavuz vd. (2015) yaptıkları çalışmada Türkiye'de çiftçilerin tarım yapmaktaki amaçlarını ve karar verme süreçlerini BWM ile incelemişlerdir. Azak vd. (2016) yaptıkları çalışmada domates tüketicilerinin dikkate aldığı kriterlerin belirlenmesi amacıyla BWM kullanmışlardır. Ahmad vd. (2017) yaptıkları çalışmada petrol ve doğalgaz sürdürülebilir tedarik zinciri yönetiminin sağlanmasına veya bozulmasına sebep olan etkenleri anlama konusunda yetersiz kaldığını belirlemiş ve bu faktörlerin tedarik zinciri yönetimi faaliyetlerine etkilerini altı dış kuvvete odaklandığını bunlarında ekonomik istikrar, siyasi istikrar, paydaş baskısı, rekabet, enerji geçişi ve düzenlemel er olduğunu tespit etmiştir. Bu faktörler içinde hangisinin daha fazla hangisinin daha az önemli olduğu ise BWM kullanılarak belirlenmiştir.

BWM kullanılarak yapılan çalışmalar, tedarikçi değerlendirme, hata türleri analizi, satın alma kriterlerinin değerlendirilmesi, tüketicilerin satın alma davranışlarının analizi gibi, genellikle İSG dıșındaki alanlardadır. Çalışma yapılan sektörler incelendiğinde ise turizm, gayrimenkul, tarım, enerji gibi inşaat sektörü dışında kalan sektörler olduğu görülecektir. Ancak bu çalışmada BWM, hem bir İSG çalışması olan risklerin değerlendirilmesi amacıyla kullanılması, hem de İSG alanında önemli bir sektör olan inşaat sektöründe gerçekleştirilmesi nedeniyle, bugüne kadar yapılan akademik çalışmalardan farklı bir nitelik göstermektedir. Ayrıca verilerin elde edildiği örneklemin, İSG alanında çalışan, sektör tecrübesi olan ve bu alanda akademik eğitim gören katılımcılardan oluşan, bilinçli ve yetkin bir grubu barındırması sebebiyle, çalışma tamamlandığında elde edilen sonuçların güvenilirliği daha yüksek olması beklenebilir. Ayrıca yapılan çalışmada, risklerin analizi için kullanılan veri toplama anketinde yer alan soruların, literatürde yer alan risk faktörlerinin toplamından oluşan meslek hastalığı, kaza tehlikesi ve yanma/kimyasal tehlike gibi risk gruplarını içermesi nedeniyle, çalışma sektörde karşılașılan risk faktörleri üzerinde, kapsayıcı olma özelliğine de sahiptir. Çalışma sonunda yapılan analizlerde, tutarlılığı düşük yanıtların veri havuzundan çıkarılması, bu şüpheli verilerin sonuçlar üzerinde yanıltıcı etkisi olmamasını sağlamış ve sonuçların güvenirliğini arttırmıştır. Bu çalışma sayesinde inşaat sektöründeki olası riskler içerisinde en önemli olanları ortaya konacak ve uzmanların bu alanlara odaklanarak riskleri daha hızlı ve etkili şekilde bertaraf etmeleri sağlanacaktır.

\section{Materyal ve Yöntem (Material and Method)}

ÇKKV, sayısal olarak modellemenin zor olduğu durumlarda, kriterlerin ağırlıklandırılması ve alternatifler arasında seçimin yapılması amaçlarıyla kullanılmaktadır. Son yıllarda risk değerlendirme tekniklerine bir alternatif yöntem olarak da kullanılmaktadır. Risk faktörlerinin gruplandırılması ve her bir faktörün-grubun ağırlıklarının belirlenmesi için uzman görüșlerinin alınması șeklinde çalıșmalar mevcuttur. Uzman görüșleri ile risk faktörlerinin birbirleri ile klyaslanarak önem derecelerinin belirlenmesi, risklerin hangisine öncelikli olarak yoğunlașılması gerektiğini gösterecektir. 
BWM, Jafar Rezeai (Delft Teknoloji Üniversitesi) tarafından 2015 yılında tanıtılmış bir ÇKKV tekniğidir. Diğer ÇKKV yöntemlerine göre çok daha pratik ve uygulanması oldukça basittir. Karar vericinin (uzman) daha az soruya yanıt vermesi beklenmektedir. Özellikle büyük problemlerde kolaylık sağlamaktadır. Karar verici, anketin başında iki uç (en iyi-en kötü) kriteri belirler, böylece hangi aralıkta puanlar vereceği fikri aklında başlangıçta oluşmuş olur.

Çok Kriterli Karar Verme problemlerinde, en iyi seçeneği belirlemek için, belli başlı kriterler açısından bir dizi seçenek değerlendirilir. BWM'de en iyi (en çok istenen veya en önemli) ile ve en kötü (en az istenen veya en az önemli) kriterler ilk aşamada karar verici tarafından belirlenir. Ardından bu en iyi ve en kötü olarak belirlenen iki kriterin her biri ile diğer kriterler arasında ikili karşılaştırmalar yapılır. Daha sonra, farklı kriterlerin görece ağırlıklarını tespit edebilmek için bir matematiksel model ortaya konur ve çözülür. Alternatiflerin farklı kriterlere göre ağırlıkları aynı işlem kullanılarak bulunur. Alternatiflerin nihai puanları, en iyi alternatifin seçildiği temelde farklı kriter ve alternatif kümelerinden ağırlıkların toplanmasıyla elde edilir (Rezaei, 2015).

\subsection{BWM'nin Avantajları ve Farkları (Differances and Advantages of BWM)}

Karar verici daha az sayıda soruya yanıt verdiği için veri ve zamanın etkin kullanımı anlamında BWM iyi bir alternatiftir. Ayrıca daha az soru daha az kafa karışıklığı yaratarak tutarlılık anlamında daha iyi sonuçlar alınmasına neden olabilir. Zıttı düşünme stratejisi de oluşacak olası tutarsızlığı hafifletmektedir. İkili karşılaștırma tabanlı yöntemlerde, ya tek bir vektör (örneğin Swing ve SMART ailesi) ya da tam bir matris (örneğin AHP) kullandığımız yöntemler bulunmaktadır. Tek vektör, zaman açısında avantajlı olurken tüm tutarlılığın kontrolünün sağlanması açısından dezavantajlıdır. Tam matris ise zaman açısından dezavantajlı olup tutarlılık kontrolü açısından daha avantajlıdır. BWM, bu iki uç noktanın arasında bir noktada bulunduğundan iki tarafın da dezavantajını azaltarak avantajını kullanma olanağı sağlar. BWM ile iki uç nokta (en iyi ve en kötü kriter) belirlenerek analiz yapıldığından, arada kalan kriterle ayrım daha iyi yapılmış olmakta ve bu nedenle çalışmada önyargı oluşmamış olmaktadır (Azak vd., 2016).

BWM diğer Çok Kriterli Karar Verme yöntemlerine kıyasla daha az ikili karşılaştırma gerektirmesi bakımından avantajlıdır. Ayrıca BWM’nin diğer Çok Kriterli Karar Verme yöntemleri ile birleştirilebilme özelliği nedeniyle alternatif yöntemlerden ayrılır. BWM'nin karşılaştırma matrislerinde sadece sayıların kullanılması nedeniyle, metot daha kolay işlem yapabilme avantajı sağlar. Ayrıca metotta türetilen son ağırlıklar, daha tutarlı karşılaştırmalar sağlaması nedeniyle güvenilir özelliktedir (Rezaei, 2015). Ahmad vd. (2017) çalışmasında BWM ile elde edilen sonuçların, diğer ikili karşılaştırma matrisleri kullanılarak elde edilen sonuçlara nazaran daha tutarlı olduğunu ortaya koymuş ve daha az ikili karşılaştırma gerektirdiği için daha avantajlı olduğunu belirtmiştir. Firmaların Ar-Ge performanslarının değerlendirilmesi konulu bir çalışmada, BWM mevcut yöntemlerle karşılaştırıldığında, daha az veri gerektirmesi ve tam bir ikili karşılaştırma verisine ihtiyaç duymaması gibi özellikleri nedeniyle tercih edilmiştir (Salimi ve Rezaei, 2016). Mevcut ÇKKV yöntemlerinde, tam bir ikili karşılaştırma matrisi yapabilmek için gereken çalışmalar çok uzun sürmektedir. Ayrıca bilgi eksikliği ve konsantrasyon sağlamada güçlükler gibi çeşitli sorunlar nedeniyle elde edilen sonuçlarda tutarsızlıklarla karşılaşılmaktadır. BWM bu sorunlara çözüm olarak ortaya çıkmıştır.

BWM'nin diğer metotlara göre birtakım farkları da mevcuttur. Örneğin bu metotta daha az karşılaştırma verisi kullanılır. Ayrıca BWM ikili karşılaştırmaların türündeki tutarsızlıkları giderir (Rezaei, 2015). BWM anlaşılması ve uygulaması kolay bir yöntemdir. Bu değerlendiricinin yapılan çalışmanın güvenilirliğini arttırmak amacıyla yapacağı kontrol etme ve gözden geçirebilmeyi kolay ve mümkün kılması nedeniyle de ekstra bir rahatlık sağlar (Rezaei vd., 2018).

\subsection{BWM'nin Uygulama Adımları (Steps of BWM)}

Ișıldar (2019) çalıșmasında BWM'nin așamalarını șu șekilde ifade etmiștir. Öncelikle karar kriterleri olușturulur, ardından bunlar arasında en iyisi ve en kötüsü belirlenir. Sonrasında Likert ölçeği kullanarak, en iyi kriterin diğerlerine ve diğerlerinin en kötü kritere olan önem dereceleri uzman tarafından belirlenir. Sonrasında bu önem derecesi vektörleri doğrusal programlama (DP) modeline alınarak optimum kriter ağırlıkları belirlenir. Temel durumda beş adımda BWM uygulanır;

Öncelikle belirlenen kriter seti içerisindeki en önemli ve en önemsiz kriterler belirlenir (1).

$\mathrm{Bu}$ kriterlere göre ikili karşılaștırmalar (Likert Ölçeği) yapılarak kriterlerin birbirine olan önem derecelerini belirlenir (2).

En önemlinin diğerlerine olan önem derecesi $\left(A_{B}\right)$ ve diğerlerinin en önemsize olan önem derecesi $\left(A_{W}\right)$ vektörleri belirlenir (3). 
W ağırlık değerlerini 3.adımdaki önem derecelerine uygun şekilde optimize edecek bir doğrusal programlama modeli kurularak çözülür (4).

W karar değişkenlerinin (faktörlerin/kriterlerin ağırlıkları) elde edilmesi amacıyla Eşitlik (1-5) ile verilen doğrusal model çözülür (5).

Modelde yer alan terimler;

$\varepsilon^{L} \quad$ : Tutarlılık Oranı

$W_{B} \quad$ : En iyi kriterin ağırlığı

$W_{W} \quad:$ En kötü kriterin ağırlığı

$A_{B j} \quad$ : En önemli kriterin j kriterine göre önemi

$A_{j W} \quad$ : J kriterinin en önemsiz kritere göre önemi

\begin{tabular}{|c|c|c|}
\hline $\min \varepsilon^{L}$ & & (1) \\
\hline $\begin{array}{l}\text { s.t: } \\
\left|W_{B}-A_{B j} W_{j}\right| \leq \varepsilon^{L}\end{array}$ & tüm j için & (2) \\
\hline$\left|W_{j}-A_{j W} W_{W}\right| \leq \varepsilon^{L}$ & tüm jiçin & (3) \\
\hline$\sum_{j} W_{j}=1$ & & (4) \\
\hline$W_{j} \geq 0 \quad$ tüm $j i c ̧$ ín & & (5) \\
\hline
\end{tabular}

Doğrusal model incelendiğinde; (1) numaralı eşitlikte amaç fonksiyonu (2-5) numaralı eşitliklerde ise modelin kısıtları görülmektedir. Amaç fonksiyonunda tutarlılık oranı minimize edilmektedir. Kısıtlardan (2) ve (3) numaralı eşitlikler sırasıyla en iyi ve en kötü kriterin ağırlığı ile diğer kriterlerin ağırlık ve önem derecesinin çarpımı ile elde edilen terimin arasındaki farkın tutarlılık oranından küçük olmasını sağlamaktadır. Tutarlılık oranı amaç fonksiyonu ile minimize edildiğinden (2) ve (3) numaralı kısıtlardaki bu farklar da minimize edilecek ve böylelikle verilen önem dereceleri ile uyumlu şekilde ağırlıklar elde edilecektir. (4) numaralı kısıt tüm faktör ağırlıklarının toplamının bire eşit olmasını ve (5) numaralı kısıt tüm ağırlıkların sıfırdan büyük olmasını sağlamaktadır.

\section{3. Çalışmanın Uygulama Alanı (Application Area of Study)}

İnşaat sektörü, gelişmekte olan ülke ekonomilerinde önemli bir yer tutmaktadır. Hem artan şehirleşme nedeniyle oluşan altyapı yatırım ihtiyacı, hem de birçok alt sektörle ilişkili olması nedeniyle en önemli sektörler arasında yer alır. Ancak yapısı gereği, hem emek yoğun bir sektördür ve yüksek sayıda çalışana sahiptir; hem de iş kazası yaşanma riski yüksektir. İnşaat sanayi, İSG yönünden en tehlikeli sektörlerden birisidir (Ceylan, 2014). Çalışma ve Sosyal Güvenlik Bakanlığına ait tehlike sınıflarını derecelendiren yönetmeliğinde inşaat sektörü 'Çok Tehlikeli İşler' sınıfında yer alır (Çalışma ve Sosyal Güvenlik Bakanlığı, 2009). İnşaat sektörünü bu kadar tehlikeli hale getiren risklerin daha detaylı bir şekilde incelenmesi gerekmektedir. İnşaat sektöründe çalışanların sağlık kontrollerinin zor olması, proje esaslı süregelen faaliyetlerde çalışanların İSG konularına odaklanmamaları ve çalışanların belirli bir süre sonra bitecek olan bir işin tehlikeleri ve sağlı̆̆a olan olumsuz etkileri ile ilgilenmemesi çarpıcıdır (Duman ve Etiler, 2013).

İnşaat sektörü kaza sayısı ve kaza sonucu oluşan etkinin büyüklüğü açısından diğer sektörlerden ayrılmaktadır. Bu nedenle inșaat sektöründe risklerin elimine edilmesi büyük önem arz etmektedir. Türkiye'de iş kazalarının \%1,6'sı ölümle sonuçlanmakta iken inşaat sektöründe bu oran \%4,7'dir. Ülkede yaşanan kazaların yaklaşık \%9'u inşaat sektöründe gerçekleşmektedir. Bu orana rağmen ülkedeki ölümlü kazaların \%26'sının inşaat sektöründe gerçekleşmiş olması, kazaların ne denli ciddi boyutlarda olduğunu göstermektedir (Toktaş ve Can, 2018). Bu da inşaat sektörünün yeni risk değerlendirme metotlarının uygulanması için isabetli bir sektör olduğu sonucunu doğurur.

İnşaat sektöründe yapılan işin niteliğinin fiziksel olarak yoğun olması ve çalışma saatlerinin uzun olması sebebiyle çok sayıda iş kazası meydana gelmektedir. Çalıșan profilinin diğer sektörlere göre daha eğitimsiz olması da buna neden olan bir diğer sebeptir (Uzun, 2012).

Farklı çalışma zorluk ve dinamikleri olması nedeniyle inşaat şantiyeleri, İSG kazalarıyla en çok karşılaşılan yerlerden birisidir (Toktaş ve Can, 2018). Ayrıca inşaat sektörü, risk yönetimi ve değerlendirmesi konusunda diğer sektörlere göre daha tecrübeli ve birikimlidir. Yöntem, yüksek risk grubu (4.derece) içinde yer aldığı için, inşaat sektöründe uygulanmıştır. Tablo 1 ile verilen ve literatürde daha önceden kullanılmış olan risk faktörleri, farklı kaynaklardan derlenerek oluşturulmuştur. Toplamda 15 adet risk faktörü, çalışmada hesaplama ve anket kolaylığg 
sağlaması açısından üç ana gruba ayrılmıştır. Yüksek sayıda faktör adedi, ikili karşılaştırma matrisini büyüteceğinden gruplama yoluna gidilmiştir. Gruplar ve risk faktörleri Tablo 1'de gösterilmiştir.

Tablo 1. Literatürden derlenen inşaat sektörü risk faktörleri (Construction risk factors retrieved from other articles)

\begin{tabular}{|l|l|l|}
\hline Ana Risk Faktörü & Alt Risk Faktörü & Kaynak \\
\hline \multirow{4}{*}{$\begin{array}{l}\text { Meslek Hastalığı } \\
\text { Tehlikesi }\end{array}$} & Toza Maruz Kalma & (Ceylan ve Başhelvacı, 2011) \\
\cline { 2 - 3 } & Ağır Kaldırma & (Ceylan ve Başhelvacı, 2011) \\
\cline { 2 - 3 } & Gürültü & (Ceylan ve Başhelvacı, 2011) \\
\cline { 2 - 3 } & Sıcakta/Soğukta Çalışma & (Ceylan ve Başhelvacı, 2011) \\
\hline \multirow{5}{*}{ Kaza Tehlikesi } & Yüksekten Malzeme Düşmesi & (Ceylan ve Başhelvacı, 2011), (Tam vd., 2004) \\
\cline { 2 - 3 } & Yüksekten Düşme & $\begin{array}{l}\text { (Ceylan ve Başhelvacı, 2011), (Tam vd., 2004), } \\
\text { (Bilir ve Gürcanl, 2015) }\end{array}$ \\
\cline { 2 - 3 } & Kazı Alanında Göçük & (Bilir ve Gürcanl, 2015), (Akay vd., 2018) \\
\cline { 2 - 3 } & Yapı Makinesi/Aracı Kazaları & $\begin{array}{l}\text { (Bilir ve Gürcanl, 2015), (Tam vd., 2004), (Ebrat } \\
\text { ve Ghodsi, 2014) }\end{array}$ \\
\cline { 2 - 3 } & Duvar/Yapı Çökmesi & (Bilir ve Gürcanl, 2015) \\
\cline { 2 - 3 } & Elle Taşıma Nedenli Kazalar & (Bilir ve Gürcanll, 2015) \\
\cline { 2 - 3 } & El Aleti Nedenli Kazalar & (Bilir ve Gürcanl, 2015), (Tam vd., 2004) \\
\hline \multirow{5}{*}{ Tehlike } & $\begin{array}{l}\text { Kimyasallara maruz kalma (Epoksi, } \\
\text { Poliüretan, Harç) }\end{array}$ & (Gül vd., 2014) \\
\cline { 2 - 3 } & Yangın, Patlama & (Aminbakhsh vd., 2013) \\
\cline { 2 - 3 } & Elektrik Çarpması, Yıldırım Düşmesi & (Aminbakhsh vd., 2013), (Bilir ve Gürcanl,, 2015) \\
\cline { 2 - 3 } & $\begin{array}{l}\text { Zehirlenme, Nefessiz kalma (Asbest, } \\
\text { Metan, Boya) }\end{array}$ & (Tam vd., 2004), (Zou ve Zhang, 2009) \\
\hline
\end{tabular}

Uğur (2006) çalışmasında inşaat sektörünün finansal, teknik veya fiziksel olabilecek kayıp veya kazançlar barındıran çeşitli riskleri barındırdığını söylemiş, bu görüşünü aşağıdaki Tablo 2 ile örneklendirmiştir.

Tablo 2. İnşaat sektöründe risk grupları (Uğur, 2006) (Risk groups for construction industry)

\begin{tabular}{|l|l|l|}
\hline Olay & Riskin Türü \\
\hline Sözleşmede yer alan ağır şartlar & Spekülatif Risk & Şirket Riski \\
\hline $\begin{array}{l}\text { Proje sırasında meydana gelen aşırı derecede } \\
\text { soğuk hava şartları }\end{array}$ & Saf Risk & $\begin{array}{l}\text { Şirket Riski / } \\
\text { Proje Riski }\end{array}$ \\
\hline $\begin{array}{l}\text { Arsa fiyatlarında ciddi artışa neden olan } \\
\text { enflasyon }\end{array}$ & Spekülatif Risk & $\begin{array}{l}\text { Piyasa Riski / } \\
\text { Endüstri Riski }\end{array}$ \\
\hline $\begin{array}{l}\text { Ulusal çapta tüm inşaat iş̧̧lerini kapsayan bir } \\
\text { grev }\end{array}$ & Saf Risk & $\begin{array}{l}\text { Piyasa Riski / } \\
\text { Endüstri Riski }\end{array}$ \\
\hline $\begin{array}{l}\text { Ekonomik bir kira oranı ile spekülatif bir yapı } \\
\text { için kiracı bulmakta zorluk yaşanması }\end{array}$ & Spekülatif Risk & Şirket Riski \\
\hline $\begin{array}{l}\text { Yapısal bir hatanın bina surveyörü tarafından } \\
\text { tespit edilmemesi }\end{array}$ & Spekülatif Risk & $\begin{array}{l}\text { Şirket Riski / } \\
\text { Bireysel Risk }\end{array}$ \\
\hline $\begin{array}{l}\text { İş sahasında yaşanan bir kaza sonucu } \\
\text { meydana gelen yaralanma }\end{array}$ & Saf Risk & Bireysel Risk \\
\hline
\end{tabular}

İnşaat sektörü sadece İSG yönetimi risk yönetimi sürecinde o kadar ileri seviyededir ki, risklerin bir kısmını sigortalayarak başka bir kuruma aktarır, bir kısmını üstlenir ve yönetir, bir kısmını ise derinlemesine çalışmalarla en aza indirmeye çalışır. Uğur (2006) çalışmasında bu durumu aşağıdaki şekilde (Şekil 1) göstermiştir. Bu nedenle inşaat sektörü yeni bir risk değerlendirme metodunun uygulanması için elverişli bir sektör olduğu söylenebilir. 


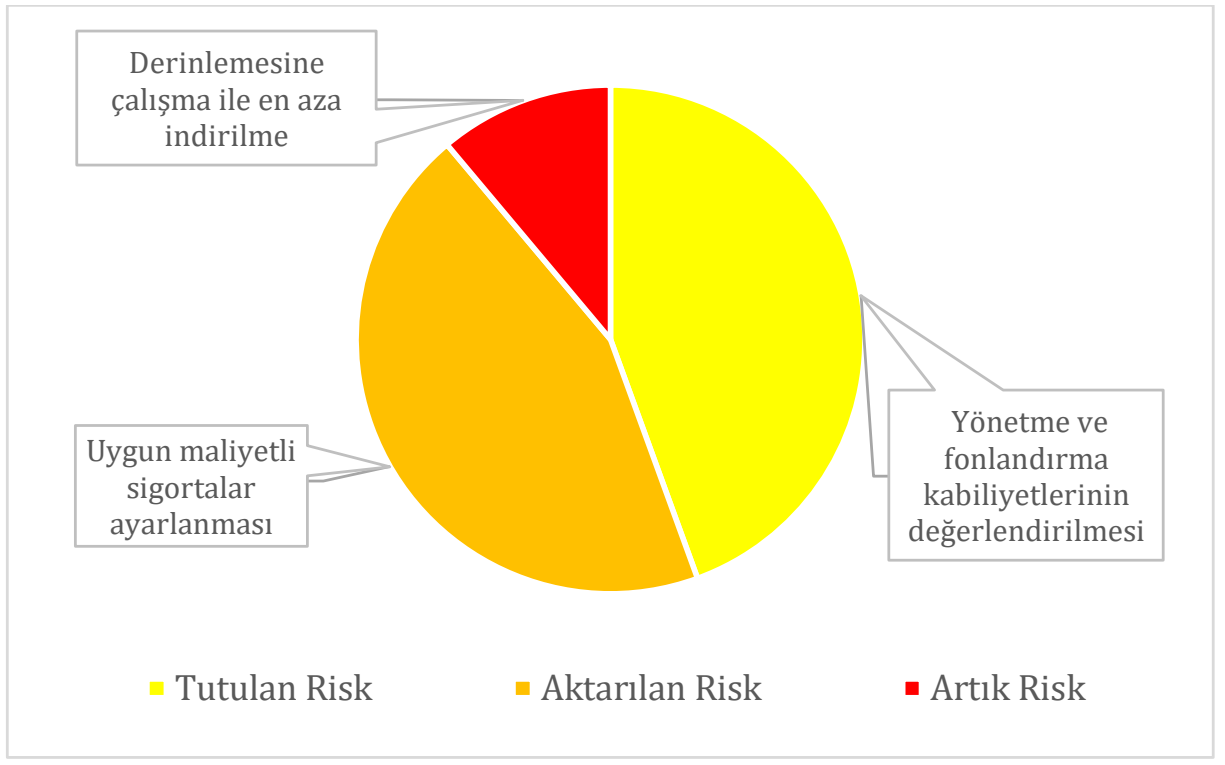

Şekil 1. Bir inșaat projesinde izlenecek risk tepkisi yaklaşımı (Uğur, 2006) (Risk response approach for a construction project)

\section{Uygulama ve Bulgular (Application and Findings)}

Ağırlıklandırılacak toplam kriter adedi 15 olduğundan sağlıklı sonuç almak ve ankette basitleștirme amacıyla kriterler belirli alt gruplara bölünmüştür. Bu gruplar, faktörlerin alındığı kaynaklar (Tablo 1) dikkate alınarak belirlenmiş olup üçe ayrılmıștır; Meslek hastalığı tehlikesi risk grubu (Toza maruz kalma, ağır kaldırma, gürültü, sıcakta/soğukta çalışma), Kaza tehlikesi risk grubu (Yüksekten malzeme düşmesi, yüksekten düşme, kazı alanında göçük, yapı makinesi/aracı kazaları, duvar/yapı çökmesi, elle taşıma nedenli kazalar, el aleti nedenli kazalar) ve Yanma/Kimyasal tehlike risk grubu (Kimyasallara maruz kalma, yangın/patlama, elektrik çarpması/yıldırım düşmesi, zehirlenme/nefessiz kalma) olarak belirlenmiștir. Bu kapsamda öncelikle grup içi klyaslama sonra da gruplar arası ağırlıkların bulunması amacıyla anket gerçekleștirilmiştir. Grup içi ve gruplar arası ağırlıklar birbirleri ile çarpılarak kriterlerin global ağırlıkları belirlenmiştir.

\subsection{Anket Tasarımı ve Uygulaması (Questionnaire Design and Application)}

Dört farklı aşamada uzman görüşlerinin alınması için anket gerçekleştirilmiştir. Anketi oluşturan dört faz ve bu fazlara ait sıralama Şekil 2 ile verilmiștir. Buna göre ankette sırasıyla meslek hastalığı, kaza tehlikesi, yanma/kimyasal tehlike alt risk grupları arasında önem dereceleri belirlenmesine yönelik sorular sorulmuştur. Sonrasında ana risk grupları arasındaki önem derecelerine yönelik sorular sorulmuştur. Faz 1'de sorulan soruların yanıtları ile meslek hastalı̆̆ı, kaza tehlikesi ve yanma/kimyasal tehlike risk gruplarının kendi içerisinde ağırlıklandırma yapılmıștır. Faz 2 aşamasında ise gruplarının birbirlerine göre olan ağırlıkları hesaplanmıştır.

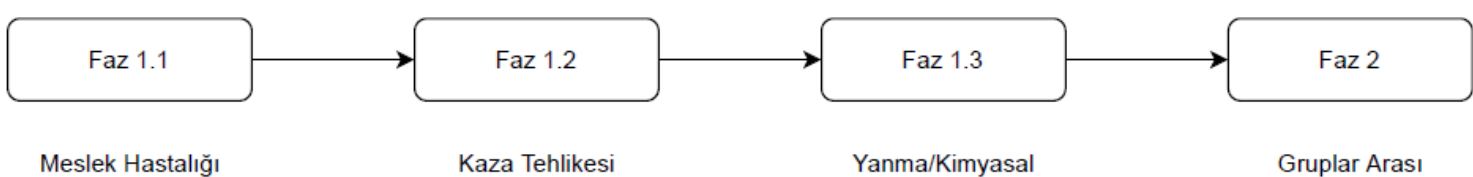

Şekil 2. Yapılan anketin aşamaları (Questionnaire phases)

Alanında uzman kișilerin görüşlerinin ve fikirlerinin alınması amacıyla düzenlenen online ankete 140 kiși katılmıș olup bunların 51 tanesi anketi tamamlamıştır. Her bir fazda uzmana, ikisi en önemli ve en önemsiz kriterin belirlenmesi ikisi de en iyiye ve en kötüye göre önem seviyelerinin belirlenmesine yönelik olmak üzere 4 soru yöneltilmiştir. Bunun yanında uzmana mesleği, İSG ve inşaat sanayi tecrübesi gibi tanımlayıcı sorular sorulmuştur. Bu soruya verilen yanıtlar katılımcıların sonuçlarının ortalaması alınırken dikkate alınmıştır. Tanımlayıcı sorulara verilen yanıtlar Tablo 3 ve 4 ile gösterilmiştir. Tablo 3'te uzmanların ISG alanında, Tablo 4'te ise inşaat sanayinde tecrübe sahibi olma durumları verilmiştir. Buna göre anketi tamamlayan 51 kişinin İSG ve inşaat sektöründeki tecrübeleri yüksektir. İki soruda da 1-10 yıl arası tecrübe sahibi olan katılımcılar \%70 seviyeleri ile çoğunluktadır. 
10-25 yıl arası tecrübe sahibi olanların oranı ise İSG alanı için \%20 olurken, inşaat sektörü tecrübesinde bu oran $\% 18,37$ olarak belirlenmiştir.

Tablo 3. İSG alanında tecrübe sahibi olma yanıtları (HSE experience answers)

\begin{tabular}{|c|c|c|}
\hline & Yanıt Sayısı & Yüzdelik Dilim \\
\hline Evet $25+$ yıl & 1 & 1,96 \\
\hline Evet $10-25$ yıl & 10 & 19,61 \\
\hline Evet 1-10 yıl & 36 & 70,59 \\
\hline Hayır & 4 & 7,84 \\
\hline
\end{tabular}

Tablo 4. İnşaat sektöründe tecrübe sahibi olma yanıtları (Construction experience answers)

\begin{tabular}{|c|c|c|}
\hline & Yanıt Sayısı & Yüzdelik Dilim \\
\hline Evet $25+$ yıl & 0 & 0 \\
\hline Evet $10-25$ yll & 9 & 18 \\
\hline Evet $1-10$ yll & 35 & 69 \\
\hline Hayır & 7 & 14 \\
\hline
\end{tabular}

Faz 1.1'de sorulan en önemli ve en az önemli faktör sorularına verilen yanıtların sonuçları Tablo 5 ile verilmiştir. Uzmanların \%50,98'i en önemli risk faktörü nedir sorusuna 'toza maruz kalma' olarak yanıt vermiș olup en düșük öneme sahip faktör sorusuna da \%56,86 ile 'sıcak/soğukta çalışma' yanıtını vermişlerdir.

Tablo 5. Faz 1.1 En yüksek/düșük öneme sahip risk faktörü yanıtları (Phase 1.1 Most/least important factor answers)

\begin{tabular}{|l|c|c|c|c|}
\hline & $\begin{array}{c}\text { Toza Maruz Kalma } \\
\text { (\%) }\end{array}$ & $\begin{array}{c}\text { Ağır Kaldırma } \\
\text { (\%) }\end{array}$ & $\begin{array}{c}\text { Gürültü } \\
\text { (\%) }\end{array}$ & $\begin{array}{c}\text { Sıcak Soğukta Çalışma } \\
\text { (\%) }\end{array}$ \\
\hline $\begin{array}{l}\text { En yüksek öneme sahip risk } \\
\text { faktörü }\end{array}$ & 50,98 & 45,10 & 1,96 & 1,96 \\
\hline $\begin{array}{l}\text { En düşük öneme sahip risk } \\
\text { faktörü }\end{array}$ & 11,76 & 7,84 & 23,53 & 56,86 \\
\hline
\end{tabular}

Tablo 6. Faz 1.2 En Yüksek/düşük öneme sahip risk faktörü yanıtları (Phase 1.2 Most/least important factor answers)

\begin{tabular}{|l|c|c|c|c|c|c|c|}
\hline & $\begin{array}{c}\text { Yüksekten } \\
\text { Malzeme } \\
\text { Düşmesi } \\
\mathbf{( \% )}\end{array}$ & $\begin{array}{c}\text { Yüksekten } \\
\text { Düşme } \\
\mathbf{( \% )}\end{array}$ & $\begin{array}{c}\text { Kazı Alanında } \\
\text { Göçük } \\
\text { (\%) }\end{array}$ & $\begin{array}{c}\text { Yapı } \\
\text { Makinesi/Araci } \\
\text { Kazaları } \\
\text { (\%) }\end{array}$ & $\begin{array}{c}\text { Duvar/Yapı } \\
\text { Cökmesi } \\
\text { (\%) }\end{array}$ & $\begin{array}{c}\text { Elle } \\
\text { Taşıma } \\
\text { Nedenli } \\
\text { Kazalar } \\
\text { (\%) }\end{array}$ & $\begin{array}{c}\text { El Aleti } \\
\text { Nedenli } \\
\text { Kazalar } \\
\text { (\%) }\end{array}$ \\
\hline En yüksek öneme sahip risk faktörü & 3,92 & 88,24 & 1,96 & 0,00 & 1,96 & 1,96 & 1,96 \\
\hline En düşük öneme sahip risk faktörü & 3,92 & 0,00 & 1,96 & 3,92 & 9,80 & 54,90 & 25,49 \\
\hline
\end{tabular}

Tablo 6'ya göre Faz 1.2'de en önemli risk faktörü \%88 ile 'yüksekten düşme' olarak belirlenmiş olup, en düşük öneme sahip faktör \%54,9 ile 'elle taşıma nedenli kazalar' olmuştur. Faz 1.2'de özellikle en yüksek öneme sahip faktörün belirlenmesinde önemli derecede bir fikir birliği oluşmuştur. 
Tablo 7. Faz 1.3 En Yüksek/düşük öneme sahip risk faktörü yanıtları (Phase 1.3 Most/least ımportant factor answers)

\begin{tabular}{|l|c|c|c|c|}
\hline & $\begin{array}{c}\text { Kimyasallara } \\
\text { Maruz Kalma } \\
\text { (\%) }\end{array}$ & $\begin{array}{c}\text { Yangın, Patlama } \\
\text { (\%) }\end{array}$ & $\begin{array}{c}\text { Elektrik } \\
\text { Çarpması, } \\
\text { Yıldırım Düşmesi } \\
\text { (\%) }\end{array}$ & $\begin{array}{c}\text { Zehirlenme, } \\
\text { Nefessiz Kalma } \\
\text { (\%) }\end{array}$ \\
\hline En yüksek öneme sahip risk faktörü & 13,73 & 45,10 & 23,53 & 17,65 \\
\hline En düşük öneme sahip risk faktörü & 47,06 & 7,84 & 21,57 & 23,53 \\
\hline
\end{tabular}

Tablo 7 incelendiğinde, en önemli risk faktörü \%45,10 ile 'yangın, patlama' olarak belirlenmiş olup en düşük öneme sahip faktör \%47,06 ile 'kimyasallara maruz kalma' olmuştur. Son aşama Faz 2'de yapılan anketin ilk iki sorusunun yanıtları Tablo 8 ile verilmiştir. Buna göre, en önemli risk grubu 'kaza tehlikesi' olarak belirlenmiş olup en düşük öneme sahip grup 'meslek hastalığı tehlikesi' olmuştur.

Tablo 8. Faz 2 En Yüksek/düşük öneme sahip risk grubu yanıtları (Phase 2 Most/least important risk group answers)

\begin{tabular}{|c|c|c|c|}
\hline & $\begin{array}{c}\text { Meslek Hastalığı } \\
\text { Tehlikesi (\%) }\end{array}$ & Kaza Tehlikesi (\%) & $\begin{array}{c}\text { Yanma/Kimyasal } \\
\text { Tehlike (\%) }\end{array}$ \\
\hline En yüksek öneme sahip risk faktörü & 9,80 & 84,31 & 5,88 \\
\hline En düşük öneme sahip risk faktörü & 60,78 & 11,76 & 27,45 \\
\hline
\end{tabular}

\subsection{Anket Sonuçlarının Model Yardımıyla Çözülmesi}

Her bir uzman ve faz için doldurulan ankete göre risk faktörlerinin ağırlıkları belirlenmiştir. Bunun için Eşitlik (15) ile verilen doğrusal programlama modeli her bir uzman ve faz için Excel ortamında çözülmüștür. Modelin çözümü ile amaç fonksiyonu (tutarlılık oranı) ve karar değişkenleri (ağırlıklar) elde edilmiştir. Faz 1.1, 1.2 ve 1.3 ile elde edilen ağırlıklar Faz 2 ağırlıkları ile çarpılarak global faktör ağırlıkları bulunmuştur. Ankete katılan 51 katılımcının sonuçlarının aritmetik ortalaması ile elde edilen faktör ağırlıkları Tablo 9 ile verilmiştir. Faktör ağırlıkları incelendiğinde en önemli risk faktörü 'yüksekten düşme' (w=0,1014), sonraki en önemli faktör 'yangın, patlama' (w=0,0962) olarak bulunmuștur.

Tablo 9. Tüm katılımcıların aritmetik ortalaması (Arithmetic mean of participants)

\begin{tabular}{|l|l|}
\hline Risk Faktörü & Ăgırlık \\
\hline Toza Maruz Kalma & 0,083 \\
\hline Ağır Kaldırma & 0,087 \\
\hline Gürültü & 0,062 \\
\hline Sıcakta/Soğukta Çalışma & 0,067 \\
\hline Malzeme Düşmesi & 0,063 \\
\hline Yüksekten Düşme & 0,103 \\
\hline Kazıda Göçük & 0,050 \\
\hline Yapı Aracı/Mak. & 0,050 \\
\hline Duvar Çökmesi & 0,052 \\
\hline Elle Taşıma & 0,044 \\
\hline El Aleti Nedenli & 0,038 \\
\hline Kimy. Maruziyet & 0,068 \\
\hline Yangın, Patlama & 0,097 \\
\hline Elektrik, Yıldırım & 0,069 \\
\hline Zehirlenme/Nefessizlik & 0,068 \\
\hline Ortalama Tutarlılık Oranı & 0,616 \\
\hline
\end{tabular}

Anketler çevrimiçi ortamda gerçekleştiğinden katılımcıların soruları doğru anlamasını sağlayacak anketör, anket süresince mevcut bulunmamıştır. Buna bağlı olarak soruların anlaşılamaması kaynaklı bazı anketlerde tutarsızlık oluşmuştur. BWM metodolojisi uygulanırken anket soruları iki yönlü sorulduğundan (aynı soru farklı soru cümlesiyle tekrar sorulduğundan) yer yer bu anketlerde tutarsızlık oluşmaktadır. İlk aşamada verilen yanıtlar ile ikinci aşamada verilen yanıtlar birbiri ile uyumlu olmalıdır. Bu uyumsuzluğa ya anket sırasında anketörün müdahalesi ile ya da sonuçlar elde edildikten sonra bu sonuçların elenmesi yoluyla müdahale edilmektedir. 
Tutarlılık oranı düşük olan anketlerin tutarlılığı yüksek kabul edilmektedir. Literatürde bazı çalışmalarda sıfıra yakın tutarlılık oranı tercih edilirken kabul gören diğer yaklaşım, eşik değeri yardımıyla tutarsızlığın belirlenmesidir. Bu nedenle 4 numaralı BWM adımının uygulanmasından önce tutarsız bulunan anketler, anket havuzundan çıkartılmıştır. Çalışmada tutarlılık kontrolü için Liang vd. (2019) tarafından yayımlanan makalede önerilen eşik değerleri dikkate alınmıștır. Bahsedilen makalede doğrusal modelin kriter sayısına ve kullanılan Likert ölçeğindeki en yüksek değere göre bir eşik değer önerilmektedir. Tutarlılık oranı sıfıra yakın değerler tercih edildiğinden Tablo 10 ile verilen eşik değerlerinin altında kalan uzman görüşleri tutarlı olarak değerlendirilmiştir. Tutarsız anketlerin dışarıda bırakılmasıyla yanıltıcı sonuçlar içerme ihtimali bulunan uzman görüşleri dikkate alınmamıştır.

Tablo 10. Tutarlılık eșik değerleri (Consistency threshold values)

\begin{tabular}{|c|c|c|c|}
\hline $\mathbf{A}_{\mathbf{B W}} \backslash$ Kriter SayıSI & $\mathbf{3}$ & $\mathbf{4}$ & $\mathbf{7}$ \\
\hline $\mathbf{3}$ & 0,2087 & 0,2087 & 0,2087 \\
\hline $\mathbf{4}$ & 0,1581 & 0,2352 & 0,3102 \\
\hline $\mathbf{5}$ & 0,2111 & 0,2848 & 0,3479 \\
\hline $\mathbf{6}$ & 0,2164 & 0,2922 & 0,4061 \\
\hline $\mathbf{7}$ & 0,209 & 0,3313 & 0,4035 \\
\hline $\mathbf{8}$ & 0,2267 & 0,3409 & 0,4379 \\
\hline $\mathbf{9}$ & 0,2122 & 0,3653 & 0,4445 \\
\hline
\end{tabular}

Verilen tutarlılık eșik değerlerine göre anketlerin tüm fazlarındaki tutarlılık seviyeleri incelenmiştir. Buna göre herhangi bir fazda tutarsızlık tespit edilen 37 adet anket çalışmanın kapsamından çıkartılmış ve geriye kalan 14 anketin sonuçları üzerinden çalışma yürütülmüştür. Buna göre tutarlı olarak belirlenen anket sonuçları Tablo 11 ile verilmiştir. Buradaki anket tutarlılık oranlarının sıfıra daha yakın olduğu görülmektedir. Tutarlılık oranının sıfıra yakın olması güvenilir BWM sonucu için istenen bir durumdur.

Tablo 11. Anket sonuçları (Questionnaire results)

\begin{tabular}{|c|c|c|c|c|c|c|c|c|c|c|c|c|c|c|}
\hline Risk Faktörü & Global & Ağırlık & & & & & & & & & & & & \\
\hline Toza Maruz Kalma & 0,014 & 0,095 & 0,077 & 0,091 & 0,027 & 0,091 & 0,107 & 0,018 & 0,070 & 0,008 & 0,076 & 0,379 & 0,100 & 0,042 \\
\hline Ağır Kaldırma & 0,059 & 0,127 & 0,046 & 0,047 & 0,117 & 0,049 & 0,155 & 0,047 & 0,034 & 0,084 & 0,030 & 0,108 & 0,050 & 0,020 \\
\hline Gürültü & 0,012 & 0,127 & 0,046 & 0,019 & 0,020 & 0,028 & 0,052 & 0,018 & 0,012 & 0,023 & 0,045 & 0,072 & 0,017 & 0,015 \\
\hline Sıcakta/Soğukta Çalıșma & 0,005 & 0,063 & 0,031 & 0,010 & 0,012 & 0,033 & 0,020 & 0,007 & 0,027 & 0,084 & 0,015 & 0,041 & 0,033 & 0,006 \\
\hline Malzeme Düşmesi & 0,060 & 0,055 & 0,093 & 0,109 & 0,126 & 0,071 & 0,047 & 0,099 & 0,153 & 0,096 & 0,113 & 0,022 & 0,066 & 0,046 \\
\hline Yüksekten Düşme & 0,246 & 0,111 & 0,093 & 0,205 & 0,314 & 0,119 & 0,099 & 0,231 & 0,153 & 0,136 & 0,191 & 0,054 & 0,123 & 0,061 \\
\hline Kazıda Göçük & 0,099 & 0,100 & 0,050 & 0,036 & 0,075 & 0,095 & 0,035 & 0,033 & 0,046 & 0,028 & 0,076 & 0,016 & 0,066 & 0,138 \\
\hline Yapı Aracı/Makinesi Kz. & 0,149 & 0,111 & 0,050 & 0,073 & 0,075 & 0,071 & 0,035 & 0,066 & 0,061 & 0,047 & 0,057 & 0,022 & 0,044 & 0,061 \\
\hline Duvar Çökmesi & 0,099 & 0,100 & 0,050 & 0,054 & 0,075 & 0,071 & 0,035 & 0,132 & 0,031 & 0,010 & 0,045 & 0,013 & 0,066 & 0,184 \\
\hline Elle Taşıma & 0,022 & 0,041 & 0,029 & 0,021 & 0,028 & 0,048 & 0,071 & 0,057 & 0,092 & 0,136 & 0,022 & 0,006 & 0,014 & 0,015 \\
\hline El Aleti Nedenli & 0,037 & 0,012 & 0,034 & 0,044 & 0,054 & 0,024 & 0,011 & 0,079 & 0,092 & 0,047 & 0,038 & 0,011 & 0,019 & 0,037 \\
\hline Kimyasallara Maruziyet & 0,014 & 0,015 & 0,053 & 0,087 & 0,044 & 0,043 & 0,129 & 0,040 & 0,054 & 0,075 & 0,050 & 0,062 & 0,037 & 0,019 \\
\hline Yangın, Patlama & 0,028 & 0,012 & 0,133 & 0,019 & 0,017 & 0,086 & 0,161 & 0,098 & 0,098 & 0,075 & 0,136 & 0,037 & 0,194 & 0,182 \\
\hline Elektrik, Yıldırım & 0,098 & 0,021 & 0,133 & 0,143 & 0,005 & 0,086 & 0,011 & 0,060 & 0,022 & 0,075 & 0,075 & 0,016 & 0,102 & 0,124 \\
\hline Zehirlenme/Nefessizlik & 0,056 & 0,010 & 0,080 & 0,043 & 0,010 & 0,086 & 0,032 & 0,015 & 0,054 & 0,075 & 0,030 & 0,142 & 0,068 & 0,050 \\
\hline Tutarlılık Oranı & 0,088 & 0,112 & 0,040 & 0,047 & 0,109 & 0,046 & 0,116 & 0,192 & 0,055 & 0,059 & 0,062 & 0,128 & 0,012 & 0,168 \\
\hline
\end{tabular}

BWM tek bir uzmandan görüş alınması için geliştirilmiş metottur. Bununla birlikte eğer birden fazla uzmanın görüşlerinin toplam sonucu alınmak istenirse bunun için geometrik veya aritmetik ortalama gibi yöntemler ilk akla gelen yöntemlerdir (Mohammadi ve Rezaei, 2019). Çalışmada birden fazla uzman görüşü birlikte değerlendirilmek istendiğinden bu amaçla aritmetik ortalama, geometrik ortalama ve ağırlıklı aritmetik ortalama yöntemleri kullanılmıştır. Bu yöntemlerin birlikte kullanılmasının nedeni farklı ortalama alma yöntemlerinin sonuçları hangi boyutta etkileyeceğinin incelenmek istenmesidir. Görüşleri alınan 14 uzmanın risk faktörü ağırlıklarının aritmetik ve geometrik ortalama sonuçları Tablo 12 ile verilmiştir. 
Tablo 12. Tutarlı anketlerin ortalamaları (Consistent results' mean)

\begin{tabular}{|l|c|c|}
\hline Risk Faktörü & Aritmetik Ortalama Ă̆ırlığ & Geometrik Ortalama Ağırlığı \\
\hline Toza Maruz Kalma & 0,0855 & 0,0564 \\
\hline Ă̆ır Kaldırma & 0,0695 & 0,0591 \\
\hline Gürültü & 0,0361 & 0,0277 \\
\hline Sıcakta/Soğukta Çalışma & 0,0277 & 0,0200 \\
\hline Malzeme Düşmesi & 0,0825 & 0,0741 \\
\hline Yüksekten Düşme & 0,1526 & 0,1357 \\
\hline Kazııda Göçük & 0,0639 & 0,0548 \\
\hline Yapı Aracı/Mak. & 0,0659 & 0,0597 \\
\hline Duvar Çökmesi & 0,0691 & 0,0534 \\
\hline Elle Taşıma & 0,0429 & 0,0317 \\
\hline El Aleti Nedenli & 0,0384 & 0,0314 \\
\hline Kimyasallara Maruziyet & 0,0517 & 0,0435 \\
\hline Yangın, Patlama & 0,0912 & 0,0654 \\
\hline Elektrik, Yıldırım & 0,0693 & 0,0470 \\
\hline Zehirlenme/Nefessizlik & 0,0537 & 0,0419 \\
\hline
\end{tabular}

Buna göre aritmetik ve geometrik ortalama sonuçlarına göre faktör ağırlıkları yakın seviyelerde bulunmuştur. En önemli ve en önemsiz faktör, geometrik ve aritmetik ortalama yöntemlerinin ikisinde de sirasıyla yüksekten düşme ve sıcakta/soğukta çalışma olarak belirlenmiştir.

Çalışmanın tutarlı anket sonuçları ağırlıklı aritmetik ortalama ile incelenmiştir. Ağırlıklı aritmetik ortalama için uzmanlara belirli bir ağırlık ataması yapılmıştır. Elde edilen sonuçta konu ile ilgili tecrübesi yüksek uzmanların ortalamaya olan etkisi yükseltilmek istendiğinden uzmanların sektördeki tecrübe süresine göre Tablo 13'teki gibi ağırlıklar oluşturulmuştur. Bu şekilde İSG ve İnşaat sektörü tecrübesi daha yüksek olan uzmanların ağırlıkları diğerlerinden yüksek kabul edilmiş ve yorumlarının sonuç üzerindeki etkisi arttırılmıştır.

Tablo 13. Uzmanların tecrübelerine göre ağırlıkları (Weights of experts corresponding to experience)

\begin{tabular}{|l|c|c|c|c|}
\hline $\begin{array}{r}\text { Inşaat Sektörü } \\
\text { Tecrübesi }\end{array}$ & Tecrübesiz & $\begin{array}{c}\mathbf{1 - 1 0} \text { yıl } \\
\text { arası }\end{array}$ & $\begin{array}{c}\mathbf{1 0 - 2 5} \text { yıl } \\
\text { arası }\end{array}$ & $\begin{array}{c}\text { 25'ten fazla } \\
\text { yıl }\end{array}$ \\
\hline Tecrübesiz & 1 & 2 & 3 & 4 \\
\hline $\mathbf{1 - 1 0}$ yıl arası & 2 & 3 & 4 & 5 \\
\hline $\mathbf{1 0 - 2 5}$ yıl arası & 3 & 4 & 5 & 6 \\
\hline 25'ten fazla yıl & 4 & 5 & 6 & 7 \\
\hline
\end{tabular}

Her bir uzman için tecrübe ağırlığı ile elde edilen faktör ağırlıkları çarpılarak ortalama alınmıştır. Ağırlıklandırma ile elde edilen ağırlıklı aritmetik ortalama sonuçları Tablo 14 ile verilmiştir.

Bu durumda en önemli faktör 'yüksekten düşme' olurken 'toza maruz kalma' faktörü ardından gelen ikinci önemli faktör olmuştur. Toplamda üç farklı ortalama alma yöntemiyle sonuçlar elde edilmiştir. Bu yöntemler aritmetik ortalama, geometrik ortalama ve ağırlıklı aritmetik ortalama yöntemleridir. Kullanılan her bir ortalama alma yöntemi ile elde edilen ağırlıklara bakılarak her bir faktör önemliden önemsize doğru sıralanmıştır. Elde edilen sonuç Tablo 15 ile verilmiştir. 
Tablo 14. Ağırlıklı aritmetik ortalama sonuçları (Weighted arithmetic mean results)

\begin{tabular}{|l|l|}
\hline Risk Faktörü & $\begin{array}{l}\text { Ağırlıkl Aritmetik } \\
\text { Ortalama }\end{array}$ \\
\hline Toza Maruz Kalma & 0,1123 \\
\hline Ağır Kaldırma & 0,0783 \\
\hline Gürültü & 0,0436 \\
\hline Sıcakta/Soğukta Çalışma & 0,0317 \\
\hline Malzeme Düşmesi & 0,0808 \\
\hline Yüksekten Düşme & 0,1481 \\
\hline Kazıda Göçük & 0,0529 \\
\hline Yapı Aracı/Makinesi Kazası & 0,0605 \\
\hline Duvar Çökmesi & 0,0555 \\
\hline Elle Taşıma & 0,0456 \\
\hline El Aleti Nedenli & 0,0362 \\
\hline Kimyasallara Maruziyet & 0,0583 \\
\hline Yangın, Patlama & 0,0784 \\
\hline Elektrik, Yıldırım & 0,0592 \\
\hline Zehirlenme/Nefessizlik & 0,0588 \\
\hline
\end{tabular}

Tablo 15. Faktörlerinin önem sıralaması (Risk factor priorities)

\begin{tabular}{|c|c|c|c|}
\hline & Aritmetik Ortalama Sıralaması & $\begin{array}{c}\text { Geometrik Ortalama } \\
\text { Sıralaması }\end{array}$ & $\begin{array}{c}\text { Ağırlıklı Aritmetik Ortalama } \\
\text { Sıralaması }\end{array}$ \\
\hline 1 & Yüksekten Düşme & Yüksekten Düşme & Yüksekten Düşme \\
\hline 2 & Yangın/Patlama & Malzeme Düşmesi & Toza Maruz Kalma \\
\hline 3 & Toza Maruz Kalma & Yangın/Patlama & Yangın/Patlama \\
\hline 4 & Malzeme Düşmesi & Yapı Aracı/Makinesi Kazaları & Malzeme Düşmesi \\
\hline 5 & Ağır Kaldırma & Ağır Kaldırma & Duvar Çökmesi \\
\hline 6 & Elektrik, Yıldırım Düşmesi & Toza Maruz Kalma & Ağır Kaldırma \\
\hline 7 & Duvar Çökmesi & Kazıda Göçük & Elektrik, Yıldırım Düşmesi \\
\hline 8 & Yapı Aracı/Makinesi Kazaları & Duvar Çökmesi & Kazıda Göçük \\
\hline 9 & Kazıda Göçük & Elektrik, Yıldırım Düşmesi & Yapı Aracı/Makinesi Kazaları \\
\hline 10 & Zehirlenme/Nefessizlik & Kimyasallara Maruziyet & Zehirlenme/Nefessizlik \\
\hline 11 & Kimyasallara Maruziyet & Zehirlenme/Nefessizlik & Kimyasallara Maruziyet \\
\hline 12 & Elle Taşıma Nedenli Kazalar & Elle Taşıma Nedenli Kazalar & Elle Taşıma Nedenli Kazalar \\
\hline 13 & El Aleti Nedenli Kazalar & El Aleti Nedenli Kazalar & Gürültü \\
\hline 14 & Gürültü & Gürültü & El Aleti Nedenli Kazalar \\
\hline 15 & Sıcakta/Soğukta Çalıșma & Sıcakta/Soğukta Çalışma & Sıcakta/Soğukta Çalıșma \\
\hline
\end{tabular}

Buna göre en önemli üç faktör, Aritmetik ortalamaya göre; yüksekten düşme, yangın/patlama ve toza maruz kalma şeklidedir. Geometrik ortalamaya göre; yüksekten düşme, yüksekten malzeme düşmesi ve yangın/patlama şeklindedir. Ağırlıklı aritmetik ortalamaya göre; yüksekten düşme, toza maruz kalma ve yangın/patlama şeklindedir. Her üç ortalama alma yönteminde de yüksekten düşme en önemli faktör olarak belirlenmiştir. Burada uzmanlar kaza yaşandığında yaşanacak can kaybı ya da sakat kalma gibi sonuçları dikkate alarak yüksekten düşme risk faktörünün iş sahasında öncelikli olarak tedbir alınması gereken risk olarak belirlemişlerdir. Bir diğer önemli nokta, meslek hastalığı alt risk faktörleri en önemli üç faktör arasına girememiştir. Bunun nedeni uzmanlar tarafından Faz 2'de meslek hastalığı risk grubunun diğer risk gruplarından daha önemsiz olarak belirlenmiş olmasıdır. 


\section{Sonuç ve Tartışma (Result and Discussion)}

Çalışmada sekiz farklı kaynaktan derlenerek oluşturulmuş olan 15 inşaat sektörü risk faktörü uzman görüşleri ile değerlendirilmiștir. Literatürde yeni çalışılmaya başlanan Çok Kriterli Karar Verme yöntemi olan BWM yaklaşımıyla 15 adet İSG risk faktörünün önem dereceleri belirlenerek ağırlıkları hesaplanmıștır. Literatürde kullanılan ÇKKV yöntemlerindeki uzmanlarla yüz yüze görüşme tekniğinden farklı bir yaklaşım kullanılmıștır. Dünyanın yaşadığı ağır pandemi koşulları nedeniyle anketler online olarak hazırlanmış olup, İSG uzmanlarından oluşan gruplar ile paylaşılarak mümkün olduğunca fazla sayıda katılımcıya ulaşılmaya çalışılmıştır. Uzman görüșleri ile faktörlerinin birbirine olan önem derecelerinden oluşan ikili karşılaștırma vektörleri elde edilmiștir. Belirlenecek faktör ağırlıklarının, mümkün olduğunca, önem dereceleriyle uyumlu olmasını sağlayan doğrusal programlama modeli çözülerek, ilk aşamada 51 adet uzmanın faktörlere verdikleri önem derecelerinden yola çıkarak faktör ağırlıkları bulunmuştur. Sonrasında tutarsız olan yanıtlar, sonuçlar üzerinde yanıltıcı etkisi olması nedeniyle çıkartılmıştır. Geriye kalan 14 uzman görüşünün sonuçları, üç farklı ortalama alma yöntemiyle (Aritmetik Ortalama, Geometrik Ortalama, Ağılıklı Aritmetik Ortalama) değerlendirilmiștir. Buna göre, uzman yanıtlarının sonuçlarında, her üç ortalama alma yöntemine göre de, yüksekten düşme en yüksek ağırlığa (öneme) sahip risk faktörü olarak bulunmuştur. Bunu takip eden faktörler, yangın/patlama, yüksekten malzeme düşmesi ve toza maruz kalma olarak belirlenmiştir.

Larsson ve Field'ın (2002) elde ettiği bulguya göre Yüksekten Düşme ve Yüksekten Malzeme Düşmesi faktörleri "en riskli" faktörler olarak tanımlanmıştır. Bilir ve Gürcanlı'ya (2015) göre Yüksekten İnsan Düşmesi faktörü aşırı riskli faktör olarak bulunmuştur. Bu sonuçlar, yayınlanan bu çalışmanın sonuçlarıyla paralellik göstermektedir. İnşaat sektöründeki İSG risk faktörlerinin BWM yaklaşımıyla incelenmesi, daha önceki çalışmalarda yapılmadığından, çalışma literatürde özgün bir yere sahiptir. İnşaat sektörü, Türkiye'de iş kazalarının ölüm veya ciddi yaralanmalarla sonuçlandığı bir sektördür. Bu nedenle üzerine yoğunlaşılması ve hızlı bir şekilde tedbir alınması gereken İSG risk faktörleri oldukça fazladır. BWM ile İSG risk faktörleri çalışmada olduğu gibi önceliklendirilmiștir.

Çalışmanın en önemli kısıtı, yüz yüze gerçekleștirilmesi gereken uzman görüşlerinin alınması aşamasının pandemi koşulları nedeniyle online ortamda anket paylaşımı ile yapılmasıdır. Bu yöntemle çok fazla sayıda uzmana ulaşılmıştır ancak anketlerdeki sorular uzmanlarca yeterince anlaşılmadığından yanıtların bir kısmında tutarsızlık oluşmuştur. Toplam dönüş alınan 51 uzmanın, yalnızca 14 tanesi tutarlı olarak tespit edilip değerlendirmeye alınmıştır. Çalışmada birden fazla uzmanla anket yapıldığından, elde edilen sonuç aritmetik veya geometrik ortalama yöntemleri ile ele alınmıştır. Ancak bu ortalama alma yöntemleri bazen uç noktalara karşı hassas olabilmektedir. Bu problemin önüne geçmek için ilerleyen çalışmalarda geçtiğimiz yıl önerilen yeni bir BWM varyasyonu olan Bayes BWM ile bu çalışma geliştirilmelidir. İlerleyen çalışmalarda araştırmacılar farklı sektörlerdeki ISG risklerini BWM ile inceleyip sonuçları diğer ÇKKV yöntemleri ile karşılaştırabilirler.

\section{Çıkar Çatışması (Conflict of Interest)}

Yazarlar tarafından herhangi bir çıar çatışması beyan edilmemiştir. No conflict of interest was declared by the authors.

\section{Kaynaklar (References)}

Ahmad, W.N.K., Rezaei, J., Sadaghiani, S., Tavasszy, L.A., 2017. Evaluation of the external forces affecting the sustainability of oil and gas supply chain using Best Worst Method. Journal of Cleaner Production, 153, 242-252.

Akay, A.O., Demir, M., Akgul, M., 2018. Assessment of risk factors in forest road design and construction activities with fuzzy analytic hierarchy process approach in Turkey. Environmental Monitoring and Assessment, 190 (9).

Alba, E., Dorronsoro, B., 2005. The Exploration/Exploitation Tradeoff in Dynamic Cellular Genetic Algorithms. IEEE, Transactions on Evolutionary Computation, 9, 26-142.

Altınel, İ.K., Öncan, T., 2005. A New Enhancement of the Clarke and Wright Savings Heuristic for the Capacitated Vehicle Routing Problem. Journal of the Operational Research Society, 56 (8), 954-961.

Aminbakhsh, S., Gunduz, M., Sonmez, R., 2013. Safety Risk Assessment Using Analytic Hierarchy Process (AHP) during Planning and Budgeting of Construction Projects. Journal of Safety Research, 46, 99-105.

Azak, Ş., Miran, B., Şimşek, B., 2016. Alternatif Üretim Teknikleriyle Üretilmiş Domateste Tüketicilerin Dikkate Aldı̆̆ı Özelliklerin Karşılaştırmalı Analizi. 12.Ulusal Tarım Ekonomisi Kongresi, 363-372, Isparta.

Bilir, S., Gürcanli, E., 2015. İnşaatlarda Yeni Bir Risk Değerlendirme Yöntemi: HRNS. 5. İşçi Sağlığı ve İş Güvenliği Sempozyumu, 157-166, İzmir.

Çakir, E., Can, M., 2019. Best-Worst Yöntemine Dayalı ARAS Yöntemi ile Dış Kaynak Kullanım Tercihinin Belirlenmesi: Turizm Sektöründe Bir Uygulama. Atatürk Üniversitesi Sosyal Bilimler Enstitüsü Dergisi, 23 (3), 1273-1300.

Çakır, E., İncioğlu, C., 2019. Türkiye Gayrimenkul Sektöründe Yabancı Yatırımcıların Beklentilerinin Best-Worst Yöntemiyle Değerlendirilmesi. International Conference on Applied Economics and Finance (ICOAEF VI 2019) \& Extended with Social Sciences, 185-187, Balıkesir. 
Çalişma ve Sosyal Güvenlik Bakanliği, 2009. “İș Sağlığı ve Güvenliğine İlişkin Tehlike Sınıfları Tebliği”. Resmi Gazete, 27320.

Ceylan, H., 2014. Türkiye'de inșaat sektöründe meydana gelen iş kazalarının analizi. International Journal of Engineering Research and Development, 6 (1), 1-6.

Ceylan, H., Başhelvacı, V.S., 2011. Risk Değerlendirme Tablosu Yöntemi İle Risk Analizi: Bir Uygulama. International Journal of Engineering Research and Development, 3 (2), 25-33.

Chang, T.L., Chen, K., Liou, J., 2019. A Novel FMEA Model Based on Rough BWM and Rough TOPSIS-AL for Risk Assessment. Mathematics, 7 (10), 874

Duman, E., Etiler, N., 2013. İnşaat Sektörü ve İşçi Sağliği. Mesleki Sağlık ve Güvenlik Dergisi, 13 (48), 30-38.

Ebrat, M., Ghodsi, R., 2014. Construction project risk assessment by using adaptive-network-based fuzzy inference system: An empirical study. KSCE Journal of Civil Engineering, 18 (5), 1213-1227.

Goldberg, D., 1989. Genetic Algorithms in Search, Optimization and Machine Learning. Reading, Boston: MA: Addison-Wesley Professional.

Gül, M., Güneri, A.F., Selvi, A.E., 2014. Bulanik Karar Verme Yaklaşimlari Kullanilarak Matris (L-Matris) Metodu Bazli Risk Değerlendirmesi, Uluslararası İş Güvenliği Sempozyumu, İstanbul.

Hinton, T.G., 2010. The Vehicle Routing Problem including a range of Novel Techniques for its Solution. Yayınlanmamıș Doktora Tezi. Bristol Üniversitesi, İngiltere.

Işildar, A., 2019. Çok Kriterli Karar Verme Yöntemleriyle Katı Atık Bertaraf Yöntemi Seçimi, Yüksek Lisans Tezi. Pamukkale Üniversitesi, Türkiye.

Jaszkiewicz, A., Ishibuchi, H., Zhang, Q., 2012. Multiobjective Memetic Algorithms. F. Neri, C. Cotta, P. Moscato (Edt.), Handbook of Memetic Algorithms, içinde (s. 201-217). Berlin: Springer-Verlag, Berlin Heidelberg.

Kara, M.E., Firat, O., 2018. Supplier Risk Assessment Based on Best-Worst Method and K-Means Clustering: A Case Study. Sustainability, 10 (4), 1066.

Laitinen, H., Vuorinen, M., Simola, A., 2012. İmalat Sanayinde İș Sağlığı ve Güvenliği Yönetimi, MESS yayınları, İstanbul.

Larsson, T.J., Field, B., 2002. The distribution of occupational injury risk in the Victorian construction industry. Safety Science, 40, 439-456.

Liang, F., Brunelli, M., Rezaei, J., 2020. Consistency issues in the best worst method: Measurements and thresholds. Omega, 102175.

Makin A.M., Winder C., 2008. A New Conceptual Framework to Improve the Application of Occupational Health and Safety Management Systems, Safety Science, 46, 935-948.

Mohammadi, M., Rezaei, J., 2019. Bayesian best-worst method: A probabilistic group decision making model. 0mega, 96, 102075.

Norouzi, A., Namin, H.G., 2019. A Hybrid Fuzzy TOPSIS - Best Worst Method for Risk Prioritization in Megaprojects. Civil Engineering Journal, 5 (6), 1257-1272.

Özkiliç, Ö., 2005. İş Sağlı̆̆ı ve Güvenliği Yönetim Sistemi ve Risk Değerlendirme Metodolojileri. Tisk Yayınları, İstanbul.

Özkiliç, Ö., 2007. İș Sağlığı, Güvenliği ve Çevresel Etki Risk Değerlendirmesi, Tisk Yayınları, İstanbul.

Rezaei, J., 2015. Best-Worst Multi-Criteria Decision-Making Method. Omega, 53, 49-57.

Rezaei, J., Roekel, W. S., Tavasszy, L., 2018. Measuring the Relative İmportance of the Logistics Performance Index Indicators Using Best Worst Method. Transport Policy, 68, 158-169.

Salimi, N., Rezaei, J., 2016. Measuring efficiency of university-industry Ph. D. projects using best worst method. Scientometrics, 109 (3), 1911-1938.

Selçuk, S., Selim, H., 2018. Mücevherat Sektöründe Kullanılan İș Sağlığı ve Güvenliği Risk Analiz Yöntemlerinden L Tipi Matris Yöntemi. Journal of Technologies and Applied Sciences, 1 (1), 21-27.

Tam, C.M., Zeng, S.X., Deng, Z.M., 2004. Identifying elements of poor construction safety management in China. Safety Science, $42(7), 569-586$.

Toktaș, P., Can, G.F., 2018. Șantiyelerin İș Sağlığı ve Güvenliği Açısından Risk Düzeylerine Göre Kemıra-M Yöntemi ile Siralanmasi. Ergonomi, 1 (3), 123-136.

Topal, İ., 2017. Risk Değerlendirme Metotları, Retrieved June, 2020, from http://www.dataakademi.com.tr/ wpcontent/uploads/2017/02/12_RD_METOTLARI.pdf.

Uğur, L. O., 2006. İnşaat sektöründe riskler ve risk yönetimi. Türkiye Müteahhitler Birliği Yayını, Ankara.

Uzun, İ.M., 2012. İnşaatlarda Yapı Makinaları Kullanımında İș Güvenliği Risk Değerlendirmesi. Yüksek Lisans Tezi. İstanbul Teknik Üniversitesi, Türkiye.

Yavuz, G.G., Miran, B., Özüdoğru, T., 2015. Cereals producers' Agricultural aims and their tendencies to sustain agricultural production in Turkey. International Conference on Eurasian Economies.

Zhang, H., Liu, B., 2009. A New Genetic Algorithm for Order-Picking of Irregular Warehouse. International Conference on Environmental Science and Information Application Technology, 1, 121-124.

Zou, P.X., Zhang, G., 2009. Comparative study on the perception of construction safety risks in China and Australia. Journal of Construction Engineering and Management, 135 (7), 620-62. 